\title{
Organizational Paranoia and Employee Performance: A Case of Nigerian Bottling Company and Seven Up Bottling Company, Benin Plants, Nigeria
}

\author{
Dr. Ihionkhan, P.A \\ Ohue Paul Itua \\ Department Of Business Administration \\ Ambrose Alli University \\ Ekpoma Nigeria
}

\begin{abstract}
The researchers observed that some employees of the companies in focus see their colleagues as unreliable. This by extension could impact the performance level of these employees. This has necessitated the determination of the effect of attribution bias on employee turn-over intention of Nigerian bottling company Benin plant and seven up bottling company, Benin plant. Survey research design was adopted for the study, a sample size of two hundred and thirty nine (239) was used for the study, Krejcie and Morgan, (1973) sampling technique was used for the study, the data collection tool employed by the researcher was the questionnaire, while the analysis of the data was done using the linear regression analysis. The findings revealed that that attribution bias impacts employee turn-over intention of Nigerian bottling company and seven up bottling company, Benin plant since ( $F$ $=974.986 ; R 2=0.847 ; P<.05)$. The researchers therefore concluded that organizational paranoia impacts employee performance of the companies in focus. It was against this backdrop that the researchers recommended a close observation of the attitudes of employees by managers of the focused firms so that they can detect when employees begin to exhibit some negative behaviours and frequent manager-employee interaction should be encouraged as it could help managers get vital information from employees.
\end{abstract}

Keywords: Organizational Paranoia, Employee Performance, Attribution Bias, Employee Turn-Over Intention.

\section{Introduction}

Paranoia as a concept has a greek origin which means mental illness (Berrios,2009). It is an instinct or thought process believed to be heavily influenced by anxiety or fear, often to the point of delusion and irrationality (World English Dictionary, 2009). Paranoid thinking typically includes beliefs of conspiracy concerning a perceived threat towards oneself. Paranoia is a term used to describe people who are preoccupied with the thought that people or others are out to get them or people always talk about them (Gale, 2008). Paranoia is distinct from phobias, which also involve irrational fear, but usually no blame. Organizational paranoia as a concept began to gain consideration in management and other fields of study in the 80's (Berrios,2009).Organizational paranoia as a concept entails making false accusations against other employees and the general distrust of others in an organization (Green, Freeman, Kuipers, Bebbington, Fowler, Dunn \& Garety 2008). This distrust of others in business organizations could impact employee performance level as employees would find it difficult to work with people they don't trust. This gives credence to the determination of the effect of organizational paranoia on employee performance in Nigerian Bottling Company Benin Plant and Seven Up Bottling Company Benin Plant. Naser, (2007) asserted that when employees are dissatisfied with the nature of employees in their work environment, they are less committed and will look for other opportunities to quit. If opportunities are unavailable, they may emotionally or mentally withdraw from the organization. Thus, organizational paranoia is an important attitude in assessing employees' intention to quit and the overall contribution of the employee to the organization.

Employee performance is the outcome of actions with the skills of employees who perform in some situation (Prasetya \& Kato, 2011). According to Suhartini, (1995) employee performance is a mutual result of effort, ability, and perception of tasks. Good performance is step towards the achievement of organizational aims.

Hence, more effort is required to improve the organizational performance. 
Negin, Omid and Ahmad, (2013) affirmed that the presence of an atmosphere of trust between individuals in an organization can improve employees' performance and raise organizational overall competitiveness. The researchers observed that some employees of the companies in focus see their colleagues as individuals that they cannot confide in. This by extension could impact the performance level of these employees. The broad objective of this study is to determine the effect of organizational paranoia on employee performance of Nigerian bottling company Benin plant and seven up bottling company, Benin plant. Specifically, this study seeks to determine the effect of attribution bias on employee turn-over intention.

\section{Review of Related Literature}

\section{Conceptual Review}

\section{Organizational Paranoia}

Organizational paranoia is a situation where employees believes that harm is occurring, or is going to occur, to him or her or that other employees has the intention to cause harm to him or her (Freeman \& Garety 2000). Harm in this case is defined as anything that employees find distressing. Harm can be physical, psychological, or social, and it can be of any severity as long as the individual finds it distressing (Freeman \& Garety, 2000). This definition of paranoia has been employed in previous research on paranoia in previous studies (Ellett, 2013; Ellett \& Chadwick, 2007), and therefore it will also be adopted in this current study.

\section{Indicators of Paranoid Individuals in Business Organizations}

Attribution Bias: paranoid individuals in an organization typically have a biased perception of reality, often exhibiting more hostile beliefs (Bentall \& Taylor, 2006). A paranoid person may view someone else's accidental behavior as though it is with intent or threatening. Poor Inter-Personal relationships: Due to the suspicious and troublesome personality traits of paranoia, it is unlikely that someone with paranoia will thrive in interpersonal relationships. Most commonly paranoid individuals tend to be lone rangers in an organization (Deutsch \& Fishman,1999).

Social Anxiety: In business organizations, paranoid individuals tend to have social anxiety (Freeman, Garety, Bebbington, Smith, Rollinson, Fowler, Kuipers, Ray \& Dunn, 2005).

\section{Causes of Paranoia in an Organization}

Social factor: An employee's social status might influence his belief system and his perception of others in an organization. Environmental factors: The nature of the work environment can impact an employee's line of thinking as well as his attitude towards others in an organization. Physical factors: Factors like brain decline and high blood pressure can lead to paranoia (Bentall \& Taylor, 2006).

\section{Attribution Bias}

Attribution bias is a cognitive bias that refers to the systematic errors made when people evaluate or try to find reasons for their own and others' behaviors. People constantly make attributions regarding the cause of their own and others' behaviors; however, attributions do not always accurately reflect reality. Rather than operating as objective perceivers, people are prone to perceptual errors that lead to biased interpretations of their social world (Hewstone, Rubin \& Willis, 2002). Attribution biases were first discussed in the 1950s and 60s by psychologists such as Fritz Heider, who studied attribution theory. Other psychologists, such as Harold Kelley and Ed Jones expanded Heider's early work by identifying conditions under which people are more or less likely to make different types of attributions. (Martinko, Harvey, Sikora, \& Douglas, 2011).

Attribution biases are present in everyday life, and therefore are an important and relevant topic to study. Since the inception of this concept, researchers have continued to examine how and why people exhibit biased interpretations of social information. Many different types of attribution biases have been identified, and more recent psychological research on these biases has examined how attribution biases can subsequently affect emotions and behavior (Darity, 2008).

The perseverative thinking questionnaire (PTQ) of Ehring, Zetsche, Weidacker, Wahl, Schonfeld and Ehlers, (2011) aided the drafting of the questionnaire for questions relating to attribution bias. It is a trans-diagnostic measure of repetitive negative thinking that captures three characteristics of repetitive negative thinking: repetitiveness, instrusiveness and difficulties to disengage. Specifically, the repetitiveness dimension was used for the study. 


\section{Employee Performance}

Aguinis (2007) opines that employee performance is about behaviour or the output of the work of employees and it is determined by a combination of declarative knowledge, procedural knowledge, motivation and commitment of the employees. Wood and Stangster (2002) states that employee performance is measured against the performance standards set by the organization. Kotler and Armstrong (2002) assert that employee performance is measured in terms of the quality of output (goods and services) produced by the employee. Employee performance is normally looked at in terms of outcomes. However, it can also be looked at in terms of behavior (Armstrong, 2001).

Kinicki and Kreitner (2007) opine that some employee key performance indicators are: Turnover intention, time required to complete task, product quality, return on training investment, revenue per employee, 360 degree feedback score, employee core competency profile, employee engagement level, organizational citizenship behavior, human capital value added, job satisfaction and employee innovation.

The definitions of various researchers on employee performance have shown that employee output level and behavior towards their job are used to determine their performance level.

\section{Turn-over Intention}

Reggio (2003) contends that employee turnover intention "refers simply to the intent of employees to leave an organization". It is a negative aspect, which might lead to the failure of employee retention strategies in organizations when an employee eventually leaves "Leaving of job appears to reflect significant work place problems, rather than opportunities for advancement into better Jobs" (Holzer \& Wissoker, 2001). Turnover of employees disrupts teams, raises costs, reduces productivity, and results in lost knowledge. It was measured through some salient indicators of employee turn-over intention.

\section{Theoretical Framework}

This study is anchored on the cognitive dissonance theory developed by Festinger (1957). Festinger (1957) stated that people will strive to minimize dissonance (inconsistency) in their environment, and that the presence of dissonance results in distress and dissatisfaction with a given situation. Employees who experience continuous dissonance in their work situation will experience distress and will contribute poorly to the organizational output, while employees who are less distressed with their work will impact the organizational output level positively.

Thus, it can be concluded that any discrepancy between employees' internal ethical standard and their perception of others will result in a moral conflict and cognitive dissonance (Festinger, 1942). This theory is relevant to the study because when employees perceive their colleagues as unreliable, it could make the work environment unconducive for them and this could impact their turn-over intention.

\section{Empirical Review}

Castilho, Xavier and Costa (2015) examined the relationship between anger, shame, depression, paranoia beliefs and employee performance in an organization. Questionnaire was used to collect data from 208 respondents, correlation was used to analyse the collected data. The findings revealed that there is a relationship between anger, shame, depression, paranoia beliefs and employee performance in an organization.

Blazer, Hays and Salive (1996) examined the factors associated with paranoid symptoms. 9.5\% adults in North Carolina were used for the study, questionnaire was the data collection tool employed, chi-square statistical tool was used to analyse the collected data. The findings revealed that these factors were associated and strongly with individuals with lower income and lower level education.

Jan-willem and Reinout (2016) examined the effect of organizational paranoia (conspiracy beliefs) on organizational commitment and turn-over intentions. All the respondents used for the study were U.S citizens, mailed questionnaire was used to collect data from 193 respondents, correlation analysis and structural equation modeling was used to analyse the collected data. The findings revealed that organizational paranoia impacts organizational commitment and turn-over intentions. The findings also revealed that organizational paranoia was dependent on leadership style. Freeman, Brugha, Meltzer, Jenkins, Stahl and Bebbington, (2010) obtained secondary data from a survey study of psychological morbidity in the British population, correlation was used to analyse the collected data. The result found strong correlations between the experience of paranoid thoughts and insomnia, anxiety, depression and irritability. 
Pinto, (2017) examined the effect of paranoia on employee performance. Randomized comparison design was used for the study, convenience sampling was used, 100 respondents was used for the study, ANOVA was used to analyse the collected data. The findings revealed that paranoia and worry affects employee performance.

\section{Gap in Knowledge}

None of the empirically reviewed examined organizational paranoia as it relates to employee performance of Nigerian bottling company, Benin plant and Seven up bottling company, Benin plant, none of the empirically reviewed identified attribution bias as it relates to turn-over intention and none of the reviewed used Krejcie and Morgan, (1970) sampling technique. This is the gap in knowledge that this study intends to fill.

\section{Methods}

\section{Research Design}

The research design adopted for this study was the survey research design. It was used because of the nature of the study. Survey research design enables the researcher to observe what happens to the sample subjects without manipulating them.

\section{Population of Study}

Table 1: Population of Employees in the Organizations of Study

\begin{tabular}{|l|l|l|l|l|}
\hline Company & $\begin{array}{l}\text { Top Level } \\
\text { Managers }\end{array}$ & $\begin{array}{l}\text { Middle Level } \\
\text { Managers }\end{array}$ & $\begin{array}{l}\text { Lower Level } \\
\text { Managers }\end{array}$ & $\begin{array}{l}\text { Total } \\
\text { Population }\end{array}$ \\
\hline $\begin{array}{l}\text { Nigerian Bottling Company } \\
\text { (NBC) Benin Plant }\end{array}$ & 72 & 167 & 282 & 521 \\
\hline $\begin{array}{l}\text { Seven Up Bottling Company, } \\
\text { Benin Plant }\end{array}$ & 45 & 84 & 194 & 323 \\
\hline Total & $\mathbf{1 1 7}$ & $\mathbf{2 5 1}$ & $\mathbf{4 7 6}$ & $\mathbf{8 4 4}$ \\
\hline
\end{tabular}

Source: Personnel Department of the Organizations of Study

Sample Size and Sampling Technique

The Krejcie and Morgan, (1970) sampling technique was used for this study. The formular is denoted below:

$$
s=\frac{x^{2} N P(1-P)}{d^{2}(N-1)+x^{2} P(1-P)}
$$

Where S= Sample Size

$\mathrm{X}^{2}=$ Table value of chi-square for 1 degree of freedom 0.05 confidence level (3.84)

$\mathrm{N}=$ population Size $(844)$

$\mathrm{P}=$ Population proportion $(0.5)$

$\mathrm{d}=$ Degree of accuracy $(0.05)$

$\mathrm{S}=3.48(844)(0.5)(1-0.5) / 0.05^{2}(844-1)+3.84(0.5)(1-0.5)$

$\mathrm{S}=(1468.56)(0.5) / 2.11+0.96$

$\mathrm{S}=734.28 / 3.07$

$\mathrm{S}=239.2=239$

Based on the above, 239 copies of the questionnaire were randomly distributed to the respondents in the organizations of study.

\section{Instrument of Data Collection}

The data collection tool employed by the researcher was the questionnaire. It was designed on a five point Likert Scale. Strongly Agreed (SD), Agreed (A), Strongly Disagreed (SD), Disagreed (D) and Undecided (U). The Bowley's (1926) allocation formula was used to determine the copies of the questionnaire to be distributed to each bottling plant. The formula is denoted thus:

$\mathrm{Nh}=\mathrm{n}(\mathrm{nh}) / \mathrm{N}$

Where $\mathrm{Nh}=$ Number of units to be distributed to each group.

$\mathrm{nh}=$ Number of respondents in each group. 
$\mathrm{n}=$ Total Sample Size.

$\mathrm{N}=$ Total Population Size.

Nigerian Bottling Company (NBC) Benin Plant:

$\mathrm{Nh}=239(521) / 844=124,519 / 844$

$=147.5=148$.

One hundred and forty eight copies of the questionnaire were distributed to the employees of Nigerian Bottling Company (NBC) Benin Plant.

Seven up Bottling Company Benin Plant:

$\mathrm{Nh}=239(323) / 844=77,197 / 844$

$=91.4=91$.

Ninety one copies of the questionnaire were distributed to the employees of Seven up Bottling Company Benin Plant.

\section{Validity of the Instrument}

Validity is the extent to which an instrument measures what it intends to measure. The content and face validity test was used by the researcher.

\section{Reliability of the Instrument}

This is a measure of the consistency of a particular instrument employed by a researcher. Split-half reliability test was used for the study. Suwannoppharat and Kaewsa, (2015) asserts that a reliability coefficient of 0.696 and above is acceptable. Therefore, a benchmark of 0.696 was used for the study.

\section{Reliability Statistics}

\section{Table 2: Scale: Reliability Statistics for Organizational Paranoia}

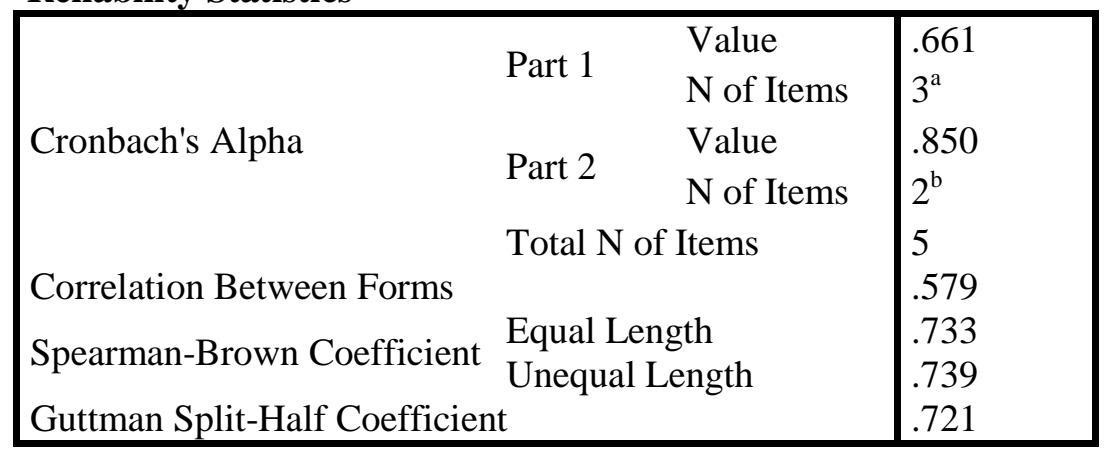

a. The items are: Q1, Q2, Q3.

b. The items are: Q3, Q4, Q5.

Formular used in calculating Split-Half reliability is given below:

$\mathrm{r} \mathrm{SB}=2 \mathrm{rhh} / 1+\mathrm{rhh}$

Where:

rhh=Correlation Between Forms

Applying the formular, we would have:

r SB $=2 * 0.579 / 1+0.579$

$\mathrm{r} \mathrm{SB}=1.158 / 1.579$

$\mathrm{r} \mathrm{SB}=0.733$

Since the split-half score of the reliability statistics for organizational paranoia 0.73 is greater than 0.696 , it shows that the instrument is reliable. 
Table 3: Scale: Reliability Statistics for Employee Performance

\section{Reliability Statistics}

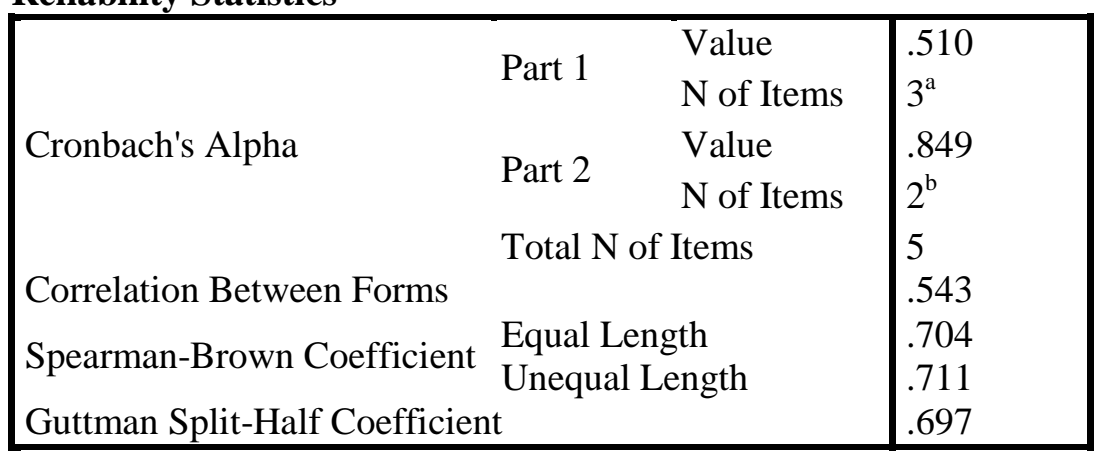

a. The items are: Q1, Q2, Q3.

b. The items are: Q3, Q4, Q5.

Formular used in calculating Split-Half reliability is given below:

r SB=2rhh/1+rhh

Where:

rhh=Correlation Between Forms

Applying the formular, we would have:

r SB $=2 * 0.543 / 1+0.543$

$\mathrm{r} \mathrm{SB}=1.086 / 1.543$

$\mathrm{r} \mathrm{SB}=0.704$

Since the split-half score of the reliability statistics for employee performance 0.70 is greater than 0.696 , it shows that the instrument is reliable. The results of the reliability test were indications of the internal consistency of the instrument.

\section{Method of Data Analysis}

Regression analysis was used to analyse the collected data. This was done with the aid of Statistical Package for Social Sciences (SPSS) version 20.

\section{Data Presentation and Analysis}

Table 4: Table of Returned and Unreturned Questionnaire

\begin{tabular}{|l|l|l|}
\hline \multicolumn{3}{|c|}{ ANALYSIS OF RETURNED AND UNRETURNED QUESTIONNAIRE } \\
\hline & Frequency & Percentage (\%) \\
\hline Returned Questionnaire (Valid) & 178 & 74.48 \\
\hline Returned Questionnaire (Invalid) & 12 & 05.02 \\
\hline Unreturned Questionnaire & 49 & 20.50 \\
\hline Total Questionnaire Administered & 239 & 100 \\
\hline
\end{tabular}

Source: Field Survey, (2018)

What is the effect of attribution bias on employee turn-over intention of Nigerian bottling company and seven up bottling company, Benin plant?

Table 5: Descriptive Statistics of the Analysed Data (Attribution bias)

\begin{tabular}{|c|c|c|c|c|c|}
\hline \multicolumn{6}{|c|}{ Descriptive Statistics } \\
\hline & $\mathrm{N}$ & Minimum & Maximum & Mean & Std. Deviation \\
\hline Q1 & 178 & 1.00 & 5.00 & 3.0056 & 1.41620 \\
\hline Q2 & 178 & 1.00 & 5.00 & 3.0112 & 1.41816 \\
\hline Q3 & 178 & 1.00 & 5.00 & 3.0225 & 1.67384 \\
\hline Q4 & 178 & 1.00 & 5.00 & 3.0056 & 1.41620 \\
\hline Q5 & 178 & 1.00 & 5.00 & 3.0000 & 1.42218 \\
\hline Valid N (listwise) & 178 & & & & \\
\hline
\end{tabular}

Source: Field survey, 2018. 
A bench-mark of 2.5 was used for the study. Since the mean values of all the questions for attribution bias are above 2.5, it shows that all the questions were acceptable for the study. Hence, they were all used for the study.

Table 6: Descriptive Statistics of the Analysed Data (Employee turn-over intention)

\begin{tabular}{|c|c|c|c|c|c|}
\hline \multicolumn{6}{|c|}{ Descriptive Statistics } \\
\hline & $\mathrm{N}$ & Minimum & Maximum & Mean & Std. Deviation \\
\hline Q1 & 178 & 1.00 & 5.00 & 2.9831 & 1.41611 \\
\hline Q2 & 178 & 1.00 & 5.00 & 2.9944 & 1.41220 \\
\hline Q3 & 178 & 1.00 & 5.00 & 3.0112 & 1.66719 \\
\hline $\mathrm{Q} 4$ & 178 & 1.00 & 5.00 & 3.0000 & 1.42218 \\
\hline Q5 & 178 & 1.00 & 5.00 & 2.9888 & 1.41417 \\
\hline Valid N (listwise) & 178 & & & & \\
\hline
\end{tabular}

Source: Field survey, 2018.

A bench-mark of 2.5 was used for the study. Since the mean values of all the questions for employee turn-over intention are above 2.5, it shows that all the questions were acceptable for the study. Hence, they were all used for the study.

\section{Test of Hypothesis}

Ha: Attribution bias affects employee turn-over intention of Nigerian bottling company and seven up bottling company, Benin plant.

Table 7: Model Summary of Regression Output a) Model Summary ${ }^{b}$

\begin{tabular}{|c|c|c|c|c|c|c|c|c|c|c|}
\hline Model & $R$ & R & Adjusted & Std. Erro & Change Sta & atistics & & & & Durbin- \\
\hline & & Square & R Square & $\begin{array}{l}\text { of th } \\
\text { Estimate }\end{array}$ & $\begin{array}{l}\mathrm{R} \text { Square } \\
\text { Change }\end{array}$ & F Change & df1 & df2 & $\begin{array}{l}\text { Sig. F } \\
\text { Change }\end{array}$ & FWatson \\
\hline 1 & $.920^{\mathrm{a}}$ & .847 & .846 & .55613 & .847 & 974.986 & 1 & 176 & .000 & 2.086 \\
\hline
\end{tabular}

a. Predictors: (Constant), Attribution Bias

b. Dependent Variable: Employee Turn-over

Table 8: ANOVA Result from Regression Output

ANOVA $^{\mathrm{a}}$

\begin{tabular}{|ll|l|l|l|l|l|}
\hline Model & & Sum of Squares & df & Mean Square & F & Sig. \\
\hline \multirow{2}{*}{1} & Regression & 301.544 & 1 & 301.544 & 974.986 & $.000^{\mathrm{b}}$ \\
& Residual & 54.433 & 176 & .309 & & \\
& Total & 355.978 & 177 & & & \\
\hline
\end{tabular}

a. Dependent Variable: Employee Turn-over

b. Predictors: (Constant), Attribution Bias

Table 9: Coefficients from Regression Output Coefficients ${ }^{\mathrm{a}}$

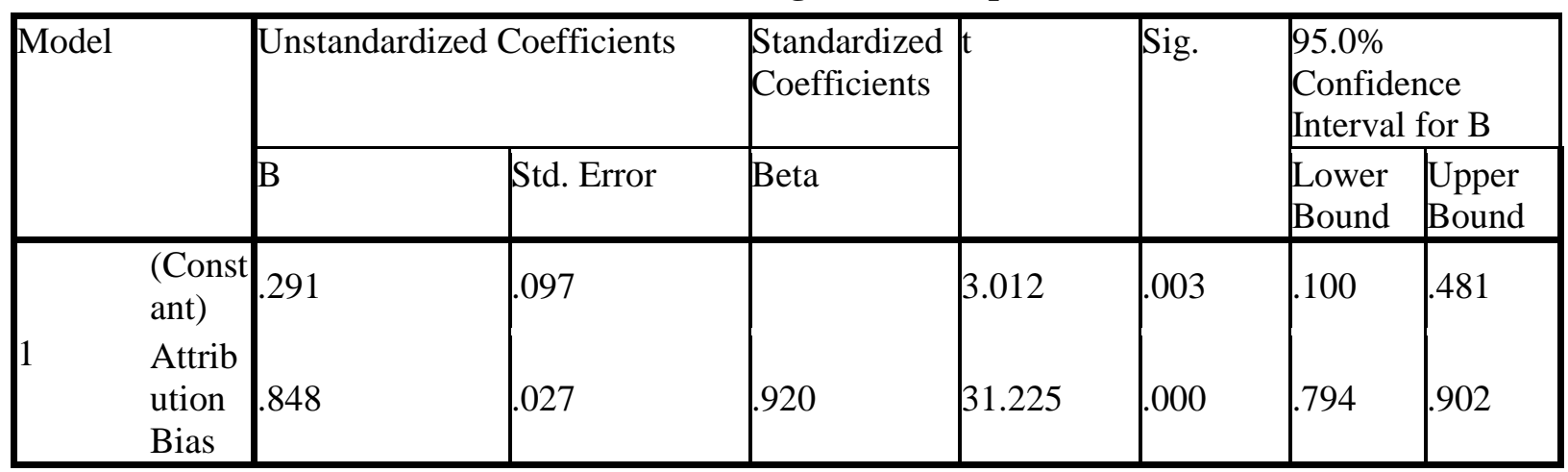

a. Dependent Variable: Employee Turn-over

The result obtained from the regression analysis shows that attribution bias has significant effect on employee turn-over intention $(\beta=0.920, \mathrm{t}=31.225, \mathrm{P}<.05)$. 
Also, attribution bias is a predictor of employee turn-over intention $(\mathrm{F}=974.986$; $\mathrm{R} 2=0.847$; $\mathrm{P}<.05)$. The predictor variable single handedly explained $84.7 \%$ of the variance in employee turn-over intention, while the remaining $15.3 \%$ could be due to the effect of extraneous variables. The durbin-watson value of 2.086 shows that there is no first serial order correlation. This makes the result respectable.

\section{Discussion of Findings}

Findings from the test of the hypothesis shows that attribution bias affects employee turn-over intention of Nigerian bottling company and seven up bottling company, Benin plant. This corroborates the work of Castilho, Xavier and Costa (2015). They examined the relationship between anger, shame, depression, paranoia beliefs and employee performance in an organization. The findings revealed that there is a relationship between anger, shame, depression, paranoia beliefs and employee performance in an organization. The result of Blazer, Hays and Salive (1996). They examined the factors associated with paranoid symptoms.

The findings revealed that these factors were associated and strongly with individuals with lower income and lower level education. In other words, employees with lower income and lower level of education tend to exhibit paranoid behaviours in an organization. The work of Jan-willem and Reinout (2016) also corroborates the result obtained from the test of the formulated hypothesis. They examined the effect of organizational paranoia (conspiracy beliefs) on organizational commitment and turn-over intentions in an organization. The findings revealed that organizational paranoia impacts organizational commitment and turn-over intentions.

\section{Summmary of Findings, Conclusion and Recommendations $\backslash$ Summary of Findings}

Findings from the test of the formulated hypothesis shows that attribution bias affects employee turn-over intention of Nigerian bottling company and seven up bottling company, Benin plant since $(\mathrm{F}=974.986$; $\mathrm{R} 2=$ $0.847 ; \mathrm{P}<.05)$.

\section{Conclusion}

Based on the findings, the researchers concludes that organizational paranoia impacts employee performance of Nigerian bottling company and seven up bottling company, Benin plant. The findings of the study show that when employees perceive their colleagues as unreliable, it could make the work environment un-conducive for them and this could impact their turn-over intention.

\section{Recommendations}

The researchers made the following recommendations based on the findings of the study:

1. A close observation of the attitudes of employees by managers of the focused firms so that they can detect when employees begin to exhibit some negative behaviours.

2. Frequent manager-employee interaction should be encouraged as it could help managers get vital information from employees.

\section{References}

Aguinis, H. J. (2007). Performance Management, New York: Upper Saddle River.

Armstrong, M. (2001). A Handbook of Human Resources Management Practices. London: Kogan Page Limited.

Bentall, R.P., \& Taylor, J.L. (2006). Psychological Processes and Paranoia: Implications for

Forensic Behavioural Sciences. Behavioural Sciences and the Law. Wiley Inter-science, 24 (3) 277-294.

Berrios, G.E. (2009). How to Write a Good History of Paranoia. Rivista Sperimentale di Freniatria 133: 109-121.

Blazer, D.G., Hays, J.C. \& Salive, M.E. (1996). Factors Associated with Paranoid Symptoms. The Gerontologist, 36(1), 70-75.

Castilho, P., Xavier, A. \& Costa, J.P. (2015). Relationship between Anger, Shame, Depression and Paranoia Beliefs. Revista de Psicopatologia y Psicologia Clinica, (20), 199-208.

Darity, W.A. (2008). "International Encyclopedia of the Social Sciences." Detroit: Macmillan Reference USA.

Deutsch, A. \& Fishman, H. (1999). "Paranoia". The Encyclopedia of Mental Health (IV). New York, NY, US: Franklin Watts.

Ellett, L., \& Chadwick, P. (2007). Paranoid Cognitions, Failure, and Focus of Attention in College Students. Cognition \& Emotion, 21(3), 558-576. 
Ellett, L. (2013). Mindfulness for Paranoid Beliefs: Evidence from Two Case Studies. Behavioural and Cognitive Psychotherapy, 41(02), 238-242.

Festinger, L. (1957). A Theory of Cognitive Dissonance. Stanford, CA: Stanford University Press.

Freeman, D., \& Garety, P. A. (2000). Comments on the Content of Persecutory Delusions: Does

the Definition need Clarification? British Journal of Clinical Psychology, 39(4), 407-414.

Freeman, D, Garety, P.A., Bebbington, P.E., Smith, B., Rollinson, R., Fowler, D., Kuipers, E.,

Ray, K. \& Dunn, G. (2005). Psychological Investigation of the Structure of Paranoia in a non-clinical Population.The British Journal of Psychiatry, 186 (5): 427-435.

Freeman, D., Brugha, T., Meltzer, H., Jenkins, R., Stahl, D. \& Bebbington, P. (2010).

Persecutory Ideation and Insomnia: Findings from the Second British National Survey of Psychiatric Morbidity. Journal of Psychiatric Research, 44(15), 1021-1026.

Gale, T. (2008). "Paranoia". International Encyclopedia of the Social Sciences. Retrieved from http://www.encyclopedia.com on the $9^{\text {th }}$ of August 2018.

Green, C., Freeman, D., Kuipers, E., Bebbington, P., Fowler, D., Dunn, G., \& Garety, P. (2008).

Measuring Ideas of Persecution and Social Reference: The Green et al. Paranoid Thought Scales (GPTS). Psychological Medicine, 38, 101 - 111.

Hewstone, M.; Rubin, M. \& Willis, H. (2002). "Intergroup Bias". Annual Review of Psychology. 53 (1): 575-604.

Holzer, H. J. \& Wissoker, D. (2001). How Can We Encourage Job Retention for Welfare Recipients. The Urban Institute Series No. A-49.

Jan-Willem, V.P., Reinout, E. (2016). Organizational Conspiracy Beliefs: Implications for Leadership Styles and Employee Outcomes. Journal of Business and Psychology, 31(4), 479-491.

Kinicki, A. \& Kreitner, R. (2007). Organizational Behavior. New York: McGraw-Hill.

Kotler, P. \& Armstrong, G. (2002). Marketing: An Introduction. 6th Ed. London: Prentice- $\quad$ Hall.

Martinko, M.J.; Harvey, P.; Sikora, D. \& Douglas, S.C. (2011). "Perceptions of Abusive

Supervision: The Role of Subordinates' Attribution Styles". The Leadership Quarterly. 22 (4): 751-764.

Naser. S (2007). Exploring Organizational Commitment and Leadership Frames within Indian and Iranian Higher Education Institutions. Bulletin of Education and Research. 29(1), 17 - 32.

Negin. M, Omid.M \& Ahmad, B.M (2013). The Impact of Organizational Commitment on Employees job performance. A study of Meli Bank. International Journal of Contemporary Research in Business. 5(5), 164-171.

Pinto, A. (2017). The Effect of Mindfulness on Paranoia, Worry, Rumination and Self-knowledge Organization. Published Research Submitted in Partial Fulfillment of the Requirements for the Degree of Doctor in Clinical Psychology (D Clin Psy), Royal Holloway, University of London.

Prasetya, A. \& Kato, M.(2011). The Effect of Financial and Non Financial Compensation to the Employee Performance. The 2nd International Research Symposium in Service Management. Yogyakarta,Indonesia.

Reggio, E. A. (2003). Introduction to Industrial/Organizational Psychology (4th Ed.).New Jersey: Prentice Hall.

Suwannoppharat, K. \& Kaewsa, A. (2015). Utilization of Content. Theme Based Instruction: An Overhaul of English Language Learning for Non-native English Learners. International Journal of English Language Education, 1(3), 115-126.

Wood, F. \& Sangster, A. (2002). Business Accounting 1. 11th Ed. London: Prentice-Hall.

World English Dictionary.(2009). Collins English Dictionary - Complete \& Unabridged 10th Edition. William Collins Sons \& Co. Ltd. 


\section{Appendix 1}

Questionnaire Items On Orgaizatioal Paraoia and Employee Performance Options: Strongly Agree = SA, Agree $=$ A, Undecided $=$ UD, Strongly Disagree $=$ SD, Disagree $=$ D. Please tick () as it represents your view $\square$

\begin{tabular}{|c|c|c|c|c|c|c|}
\hline & $\begin{array}{l}\text { Questionnaire Item for Independent Variable(Organizational } \\
\text { paranoia) }\end{array}$ & & & & & \\
\hline No & Attribution Bias & $\begin{array}{l}\text { SA } \\
5\end{array}$ & $\begin{array}{l}\mathbf{A} \\
\mathbf{4}\end{array}$ & $\begin{array}{l}\text { UD } \\
3\end{array}$ & $\begin{array}{l}\text { SD } \\
2\end{array}$ & $\begin{array}{l}\mathbf{D} \\
\mathbf{1}\end{array}$ \\
\hline 1 & You always quarrel with other employees in your department. & & & & & \\
\hline 2 & $\begin{array}{l}\text { You feel that some of your colleagues always report your wrong } \\
\text { doing to your head of department. }\end{array}$ & & & & & \\
\hline 3 & You don't trust most employees in your department. & & & & & \\
\hline 4 & $\begin{array}{l}\text { There are some employees in your department you don't like } \\
\text { working with. }\end{array}$ & & & & & \\
\hline \multirow[t]{3}{*}{5} & $\begin{array}{l}\text { There are some employees in your department that won't like } \\
\text { you to be promoted. }\end{array}$ & & & & & \\
\hline & Dependent Variable (Employee Performance) & & & & & \\
\hline & Employee turn-over intention & & & & & \\
\hline 1 & $\begin{array}{l}\text { There are occasions when you have thought of leaving your } \\
\text { organization. }\end{array}$ & & & & & \\
\hline 2 & $\begin{array}{l}\text { Since you joined your organization, you have attended } \\
\text { employment interview in other organizations. }\end{array}$ & & & & & \\
\hline 3 & $\begin{array}{l}\text { If you gain employment else where, you will leave your } \\
\text { organization. }\end{array}$ & & & & & \\
\hline 4 & $\begin{array}{l}\text { You are happy with the working environment of your } \\
\text { organization. }\end{array}$ & & & & & \\
\hline 5 & You would like to retire in your organization. & & & & & \\
\hline
\end{tabular}

